\title{
Perhekumppanuus ja perheen kiinteys
}

Valtiot. tri KALEVI HEINILA

Helsingin yliopiston sosiologian laitos

\section{Perheen rakennemuutos}

Länsimaisen yhteiskunnan teollistuminen ja kaupunkimaistuminen ovat aikaansaaneet monia sopeutumisongelmia, joista urbaanisen perheen ongelma on keskeisimpiä. Yhteiskunnan kehityksestä kiinnostuneet väestö- ja yhteiskuntapoliitikot seuraavat huolestuneina nykyperheen pysyvyyttä ilmaisevien osoittimien lukemia, jotka yleensä, lukuunottamatta eräitä satunnaistekijöiden aikaansaamia poikkeavuuksia, osoittavat perheen kiinteyden heikkenemistä. Tämä suunta esiintyy melko selvänä esimerkiksi rikkoutuneiden avioliittojen lukumäärän kehityksessä. Avioeroja oli 1000 henkilöä kohti Suomessa vuosina $1931-350.36$ ja 20 vuotta myöhemmin eli vuosina 1951-55 0.85 . Kaupunkiavioerojen suhdeluvuissa näkyy trendi vielä selvempänä: vv. 1931—35 suhdeluku oli 1.01 (vain kaupungit huomioonotettu) ja vv. 1951—55 1.75 (kaupungit ynnä kauppalat). Avioerojen yleistyminen maassamme on seurauksena siis pääasiassa urbaanisen perheen hajaantumisesta (ks. Allardt, 1953, 41).

Kehityshistoriaa tutkineet ovat osoittaneet, että perheen tehtäväalue on yhteiskuntakehityksen mukana suuresti supistunut. Agraarisen yhteiskunnan perhe oli sekä taloudellisen että henkisen toimeentulon ja sosiaalisen huollon suhteen jokseenkin omavarainen. Perhe antoi leivän, se huolehti sairaistaan ja muista huollon tarpeessa olevista jäsenistään; se antoi lapsille sen kasvatuksen ja koulutuksen, mikä oli tarpeen elämäntaipaleella. Perhe oli ajanvietteiden ja muiden vapaa-ajan rientojen keskuksena. Myös uskonnollinen harrastus keskittyi useimmiten kodin piiriin. Perhe huolehti siis pääasiassa yksin jäsentensä hengen kuin myös ruumiin kaikinpuolisista tarpeista. Tämä lähes täydellinen omavaraisuus oli samalla takeena perheen vakaisuudesta ja koossapysymisestä. Vakaisuutta olivat omiaan lujittamaan vielä vankat, avioliiton rikkomattomuutta ja pyhyyttä tähdentävät vanhat kristilliset perinteet, joiden noudattamista naapurit, suku ja ystävät tarkoin valvoivat.

Tiedämme, että perheen tehtävät kaupungistuneessa yhteiskunnassa ovat suuresti vähentyneet. Se tyydyttää nykyisin harvalukuisampia tarpeita kuin aikaisemmin. Suuresti kohonnut vaatimustaso elämän monilla aloilla on johtanut uuteen tehtävienjakoon ja yhteiskunnan uudelleen 
organisoitumiseen. Kehitys on synnyttänyt tehtäviinsä erikoistuneet työorganisaatiot, kasvatus- ja koulutusinstituutiot, vapaa-ajan pyrintöjä edustavat järjestöt ja huvielämän kaupalliset yritykset mutta myös sosiaalihuollon eri laitokset. "Ravintolat tarjoavat ruokaa, näyttämöt, elokuvat ja radio huvituksia ja juoruja; on pesuloita ja kemiallisia pesuloita ja liikkeitä, joissa parsitaan sukkia ja säilytetään talvivaatteita, pestään hiuksia, hoidetaan kynsiä ja kiilloitetaan jalkineita " (Mead, 324). Monet sellaiset tehtävät, joista aikaisemmin perhe yksin huolehti, ovat siirtyneet perheen ulkopuolisille erikoistuneille laitoksille. Tässä mielessä pitää paikkansa, että perheen merkitys on kehityksen johdosta tuntuvasti vähentynyt.

Perheen tehtäväalueen supistaminen on heikentänyt perhettä. Tässä pätee silloin pienryhmätutkimuksen hypoteesi: mitä useampia yksilön tarpeista tyydytetään sosiaalisessa järjestelmässä, sitä kiinteämpi on järjestelmä (Karlsson, 1951, 26). Kehityksen mukana ovat sitäpaitsi lakeihin, asetuksiin ja kristillisiin perinteisiin perustuvat, avioliiton pysyvyyttä tukevat normit väljentyneet ja samalla väljähtyneet. Ne eivät enää velvoita avioliiton rikkomattomuuteen samalla voimalla kuin aikaisemmin (vrt. Karlsson, 1959, 79-81). Vanha omavarainen, tehtäviltään monitahoinen, institutionaalinen perhetyyppi on yleisesti muuttumassa 'vierasvaraiseksi', tehtäviltään erikoistuneeksi, mutta kumppanuutta tähdentäväksi perhetyypiksi, joka on osoittautunut horjuvammaksi ja lyhytikäisemmäksi kuin edeltäjänsä (ks. Burgess-Locke, 26-28).

\section{Perhekiinteyden häiriötekijöitä}

Tehtäväalueen supistumisen ja muiden kehityshistoriallisten tekijöiden avulla ei kuitenkaan voida selittää sitä, miksi toiset nykyperheet ovat kiinteämpiä ja stabiilimpia kuin toiset. Nykyperheen kiinteyden vaihtelua tutkineet sosiologit viittaavat usein aviollisen sopeutumisen ja tyytyväisyyden merkitykseen. Aviollista sopeutumista on perusteellisesti selvittänyt $\mathrm{mm}$. ruotsalainen Georg Karlsson. Hän kytkee aviollisen sopeutumisen tyytyväisyyteen väittäen, että tyytyväisyyden aste määrää perheen ja myös muiden ryhmien kiinteyden. Ryhmän jäsenet ovat motivoidut jatkamaan yhdessäoloa vain, jos ryhmän antama tyytyväisyys on riittävä kunkin jäsenen kohdalla (Karlsson, 1951, 26). Karlsson erittelee lähemmin tyytyväisyyden osa-alueita erottaen toisistaan emotionaalisen, sukupuolisen, taloudellisen, lasten kasvatukseen, statuksen saamiseen ja vapaaajan käyttöön perustuvan tyytyväisyyden alueet (Karlsson, 1951, 23). Missä määrin avioliitto antaa puolisoille tyydytystä eri alueilla, siihen perustuu avioliiton pysyvyys entistä enemmän, koska ulkonaiset, institutionaaliset tukitekijät ovat voimassaan heikentyneet (vrt. Karlsson, 1951, 23). Jos väittämä pitää paikkansa, silloin olisi tärkeätä selvittää tyytyväisyyden 
eri osa-alueilla, missä olosuhteissa ja miten voidaan saavuttaa 'riittävä' tyytyväisyys. Käytännössä tähän jo pyritäänkin aviopuolison valintaa, avio- ja perhe-elämää sekä sukupuoli- ja lasten kasvatusta koskevalla neuvonta- ja valistustyöllä.

Yhteiskunnan järjestyksen kannalta tärkeät tehtävät ja tarpeet institutionaalistuvat eli vakiintuvat säädösten, normien ja tapojen muodossa. Avioliitto ja perhe huolehtivat tärkeistä tehtävistä. Ne ovat yhteiskunnan keskeisiä sosiaalisia instituutioita, joiden tila vaikuttaa koko yhteiskunnan hyvinvointiin. Perheinstituutiossa jäsenten velvollisuudet ja oikeudet ovat täsmennetyt. Aviopuolisoilta vaaditaan tai odotetaan tietynlaista, yleisesti hyväksyttyä käyttäytymistä. Sanotunlaiset rooliodotukset eivät tietenkään ole vain Maijan ja Matin päähänpistoja, vaan ne ovat tarkoituksenmukaisuuden ja vuosisataisten perinteiden sanelemia sääntöjä, joiden tarkoitus on tukea järjestystä ja pysyvyyttä. Perhesosiologina tunnettu William Goode sanookin, että

aviomiehen ja aviovaimon rooleihin sisältyy implisiittisesti myös yhteiskunnan eri intressiryhmien vaateet. Avioliitto ei ole missään yhteiskunnassa puhtaasti aviopuolisoiden sopimus. Kuitenkin tämä 'kolmas intressiryhmä' voi vaihdella eri kulttuureissa: milloin se on suku, milloin yhteiskunta jne. (Goode, 1956, 206).

Aviollisen tyytyväisyyden ja perheen kiinteyden kannalta on tärkeää, että aviopuolisot tuntevat nämä rooliodotukset, tietävät, mitä heiltä aviomiehen ja aviovaimon asemassa odotetaan ja että he käyttäytyvät näiden odotusten mukaisesti. Aviollinen sopeutuminen on suuressa määrin puolisoiden eri roolien yhteensovittamisen prosessi (vrt. Karlsson, 1951, 31). Tämä näkyy selvästi niiden ongelmien luonteessa, jotka usein avioliiton alkuvuosina koettelevat sen pysyvyyttä. Näiden sopeutumisvuosien vaikeudet heijastuvat $\mathrm{mm}$. miesten vapaa-ajan käytössä. Niinpä erään tutkimuksen mukaan nuorten aviomiesten vapaa-ajan käyttö muistuttaa suuresti poikamiesten vapaavalintaista, huoletonta vapaa-ajan käyttöä, vaikka he jo tuntisivatkin aviomiehen rooliin kuuluvat vapaa-ajan käytön vaatimukset. Siirtyminen aviomiehen rajoitetumpaan vapaa-ajan rooliin voi olla vaikeaa, ja sopeutuminen saattaa kestää vuosia (Heinilä, 63-64).

Avioliiton roolivaatimusten ja käyttäytymisen yhteensovittamisen vaikeus ja etenkin eri roolien aikaansaamat ristikkäispaineet voivat aikaansaada jännityksiä ja horjuttaa avioliiton pysyvyyttä. Sosiologisesti keskeisiä tutkimuskohteita ovat juuri tällaiset jännityspisteet, joissa arvot, normit ja roolivaatimukset joutuvat ristiriitaan keskenään eli ne "tilanteet, joissa meillä on moraalinen valintamahdollisuus hyvän isän, hyvän aviopuolison, hyvän työntekijän tai lojaalin kansalaisen roolien välillä«, kuten Goode sanoo (6).

Näitä jännityspisteitä esiintyy usein juuri vapaa-ajan käytön alueella. Sten Hultgren ja Ingmar Stoltz ovat avio-onnea selvittävässä tutkimukses- 
saan pyrkineet paikallistamaan perheyhteyttä vaarantavat uhkatekijät ja määrittämään niiden yleisyyteen perustuvan vaara-asteen. Vaarallisimmaksi uhkatekijäksi osoittautui aviomiehen vapaa-ajan käyttö. Seuraavat järjestyksessä olivat uskottomuus, alkoholin väärinkäyttö ja perheen laiminlyönti työn vuoksi (Hultgren-Stoltz, 12-13).

\section{Vapaa-ajan käyttö perheen kiinteyden häiriötekijänä}

Gooden käsityksen mukaan moraaliset ja eetilliset normit kieltävät avioliitossa sellaisen käyttäytymisen, mikä voi aiheuttaa ristiriitaa ja jännitystä. Jo avioliiton hyväksyminen ja solmiminen merkitsee sitä, että samalla hyväksytään joukko yhteisiä arvoja, mitkä ennalta ehkäisevästi torjuvat ristiriitoja. Tällaisista avioliiton pysyvyyttä edistävistä arvoista Goode mainitsee esimerkin: Vaimoni ja minä olemme sosiaalistuneet uskomaan ja hyväksymään, että meidän on avioliitossa elettävä yhdessä (8).

Pyrittäessä selvittämään, minkälainen vapaa-ajan käyttö on avioliiton ja perheen normien mukaista, on lähtökohdaksi otettava luonnollisesti näiden normien selvittäminen. Tässä avautuu laaja tutkimustehtävä. Sosiaaliset normit määrittelevät, mikä käyttäytyminen on kiellettyä, mikä taas sallittua tietyssä roolissa. Sallituista käyttäytymismuodoista toiset ovat suositeltavia, toiset valinnanvaraisia ja eräät taas ehdottomia. Sosiaaliset pakotteet, jotka osaltaan aikaansaavat käyttäytymisen mukautumisen normeihin, vaihtelevat vastaavasti velvoittavuudessaan ja voimassaan (vrt. Goode, 203).

Tutkimuksissa todettu tärkeä vapaa-ajan käytön hyväksyttävyyden peruste sisältyy Gooden äskeiseen esimerkkiin, jossa hän tähdensi avioliiton yhteyden merkitystä. Pitänee melko yleisesti paikkansa, että aviopuolisoitten roolivaatimukset puoltavat sellaista vapaa-ajan käyttöä, joka tapahtuu yhdessä perheen jäsenten kanssa. Ernest W. Burgess ja Paul Wallin ovat todenneet, että $61 \%$ niistä kihlapareista, joiden kihlaus johti avioon, vietti vapaa-aikansa pääasiassa yhdessä, mutta purkautuneista $49 \%$ (291). Vapaa-ajan käytön yhteisyyden puolesta puhuvat myös Karlssonin eräät tutkimustulokset. Aviolliseen tyytyväisyyteen hän totesi liittyvän mm. sen, että molemmat aviopuolisot pitivät lukemisesta, kun taas erimielisyys tässä liittyi tyytymättömyyteen. Tyytyväisyyteen kytkeytyi myös molempien piittaamaton tai kielteinen suhtautuminen vieraskutsuihin ja tyytymättömyyteen aviopuolisoitten erilainen suhtautuminen. Samanlainen suhtautuminen urheiluun kytkeytyi tyytyväisyyteen ja vastaavasti erilainen tyytymättömyyteen (Karlsson, 1951, 111-112).

Purnell Benson on Burgess-Wallinin follow-up-tutkimuksen aineistoa uudelleenanalysoimalla päätynyt seuraaviin tuloksiin. Sopeutuneille aviopareille on tunnusomaista molemminpuolinen ja yhteinen kiinnostus 
kotiin, lapsiin, romanttiseen rakkauteen ja uskontoon. Heille on myös ominaista yhteinen kiinnostuksen puute huvittelunluontoisiin, kaupallisiin vapaa-ajan vietteisiin. Molempien aviopuolisoiden kiinnostus yhteiskunnalliseen ja järjestötoimintaan näyttää kytkeytyvän hieman yllättävästi sopeutumattomuuteen. Yleisenä johtopäätöksenä tutkija esittää, että yksilökeskeiset ja huvittelunluontoiset vapaa-ajan pyrinnöt ovat harmonisen ja onnellisen avioliiton vaarana (Benson, 1955, 108).

Aviollisen sopeutuvuuden (tai perheen kiinteyden) ja vapaa-ajan käytön välillä vallitseva riippuvuus ei ole kuitenkaan yksiselitteinen ja suoraviivainen. Esimerkiksi Goode tähdentää, ettei niinkään pelkkä vapaa-ajan käytön yhteisyys kuin $\mathrm{latu}$ ja mieli (meaning) ovat ratkaisevia. Aviomiehen harrastukset voivat olla yhdistäviä, vaikka ne eivät olisikaan yhteisiä, jos mies harrastaa niitä esim. kotona. Traditionaalisella perheellä ei pari sukupolvea sitten ollut juuri nimeksikään yhteisiä harrastuksia. Yhteisosallistumisen alue oli suppea: vaimo ja mies toimivat erillään omissa askareissaan. Toiminnalle oli kuitenkin tunnusomaista $\mathrm{k}$ o t ikeskeisy ys - ja tämä lujitti perheen kiinteyttä (Goode, 93).

Aviopuolisoitten roolivaatimukset suosivat kotipiirissä tapahtuvaa vapaa-ajan käyttöä. Tämä roolivaatimus tuli eräässä tutkimuksessa selvästi esille aviomiesten reaktioissa seuraaviin väittämiin:

1. vapaa-aika on pääasiassa käytettävä järjestö- ja yhdistystoimintaan tai muuhun yhteiskunnalliseen ja aatteelliseen toimintaan,

2. vapaa-aika on pääasiassa käytettävä kanssakäymiseen ja seurusteluun ystävien ja tovereitten kanssa,

3. vapaa-aika on pääasiassa vietettävä kodin ja perheen piirissä.

Tutkimuksen 21-35-vuotiaista aviomiehistä $56 \%$ suosi kotikeskeistä vapaa-ajan käyttöä mutta poikamiehistä vain $21 \%$ (Heinilä, 60-61).

Maaseutuelämän suurempi kotikeskeisyys on ilmeisesti perheen kiinteyttä ylläpitävä tekijä. Tämä ehkä heijastuu myös aviomiesten roolivaatimusten erilaisuutena maaseudulla ja kaupungissa. Goode antaa tästä viitteitä tutkiessaan avioerossa elävien äitien sopeutumista yhteiskuntaan. Näiltä naisilta tiedusteltiin $\mathrm{mm}$. syytä avioeroon. Sellaisista maaseutuvaimoista, joiden mies oli syntyperäinen kaupunkilainen, $38 \%$ valitti «kotielämän rakoilemista «. Tässä tapauksessa siis vaimojen rooliodotukset viittasivat kotikeskeiseen perhe-elämään, joita odotuksia aviomiehen käyttäytyminen ei vastannut. Vastakkaisesti oli todettavissa harvempia valituksia tässä suhteessa niiden kaupunkivaimojen taholta, joiden mies oli maaseudulta. Vain $17 \%$ naisista valitti. Näillä vaimoilla oli «matala odotustaso « ja miehillä taas maaseutuperinteinen, kotikeskeinen käyttäytyminen (126). Mielenkiintoisia ja tärkeitäkin tutkimustehtäviä tarjoutuisi runsaasti pyrittäessä selvittämään eri perheiden vapaa-ajan käytön kotikeskeisyyttä ja tässä suhteessa erilaisten perhetyyppien pysyvyyttä ja kiinteyttä (ks. Burgess-Wallin, 1953, 446). 


\section{Perhekumppanuus}

Perheen kiinteyttä ja aviollista tyytyväisyyttä tutkittaessa voidaan käyttää hyväksi George Homansin väittämiä ryhmän kolmen peruselementin: toiminnan, vuorovaikutuksen ja sentimenttien, keskinäisistä suhteista. Analysoidessaan Tikopian luonnonheimon perhe-elämää Homans toteaa, että perheessä jäsenten väliset emotionaaliset siteet (sentimentit) eivät esiinny tyhjiössä, vaan ovat sellaisten toimintojen seuraamuksia, joihin jäsenet yhdessä osallistuvat. Yhteisen yrityksen, perheen, ylläpitämistä ja turvaamista edistävään toimintaan perustuvat ne lujat tunnesiteet, jotka ovat ominaisia Tikopian, mutta myös kaikille 'vanhanaikaisille' perheille (Homans, 277). Yleistävästi Homans sanoo, että emotionaalisia suhteita henkilöiden välillä ylläpitävät lukemattomat toistuvat työn ja vapaa-ajan tapahtumat, joihin henkilöt yhdessä osallistuvat (134). Vuorovaikutuksen ja emootioiden suhde on kaksisuuntainen Homansin hypoteesin mukaan: "Jos vuorovaikutus henkilöiden välillä lisääntyy, voimistuu myös pitämisen tunne - ja päinvastoin « (112). Myös Heider esittää samantapaisen väitteen (Heider, 188-189). Homans lisää kuitenkin varauksen: jos toisen henkilön käyttäytyminen ärsyttää, niin lisääntynyt vuorovaikutus aikaansaa negatiivisten sentimenttien voimistumisen (116, vrt. Heider, 189-190).

Robert O. Blood ja Donald M. Wolfe ovat äskettäin julkaisseet Detroitin alueella, U.S.A:ssa, suoritetun laajan, 909 aviovaimon haastatteluun perustuvan tutkimuksen "Husbands \& Wives «, jonka tulokset antavat tukea Homansin hypoteesille. Tutkimustehtävänä oli $\mathrm{mm}$. vaimon ja aviomiehen vuorovaikutusjärjestelmän kuvaus erilaisissa perheissä ja tämän kumppanuudeksi kutsutun suhdejärjestelmän yhteyksien tiedusteleminen. Aviopuolisoiden kumppanuus määritellään tässä tutkimuksessa operationaalisesti yhdessä osallistumisen mukaan (yhdessä osallistumista kutsutaan myöhemmin yhteisosallistumiseksi). Detroitin tutkimuksen aviovaimoista $48 \%$ piti kumppanuutta avioliiton tärkeimpänä ominaisuutena ja ainoastaan $14 \%$ jätti sen mainitsematta kolmen tärkeimmän ominaisuuden joukossa. Muut näkökohdat: «rakkaus«, «keskinäinen ymmärrys«, «lasten saaminen « ja «elintaso «, jäivät valinnassa selvästi toissijaisiksi. Tutkijat toteavatkin, että "kumppanuus on kehittynyt avioliiton arvostetuimmaksi ominaisuudeksi « (Blood-Wolfe, 150). Johtopäätöstä tukee myös se tutkimuksen havainto, että toiseksi yleisimpänä erimielisyyden aiheena aviovaimot mainitsivat kumppanuuden puutteen vapaa-ajan käytössä (241).

Blood ja Wolfe eivät ole käyttäneet hyväkseen Homansin hypoteeseja, mutta ovat todenneet, että kumppanuusperheissä pitämisen tunteen ilmaisut ovat yleisempiä kuin ei-kumppanuusperheissä (224-226). Tämä tulos tukee edellä mainittua Homansin hypoteesia vuorovaikutuksen ja sentimenttien toisiaan vahvistavasta yhteydestä. Hypoteesia tukee myös se tutki- 
joiden havainto, että aviollinen tyytyväisyys on suurempi niissä avioliitoissa, joissa kumppanuus eli aviopuolisoiden yhteisosallistuminen on yleisempää (260).

\subsection{Kumpanuuden kasatuminen}

Helsingin yliopiston sosiologian opiskelijoiden harjoituskurssillaan keräämä tutkimusaineisto, joka perustuu 454 helsinkiläisen aviovaimon haastatteluun, antaa mahdollisuuden tarkastella aviopuolisoiden kumppanuuden eräitä ilmenemismuotoja (perusjoukosta ja otoksesta ks. Eskola, 86-87). Antti Eskola on osoittanut, että hänen hypoteesinsa "roolijako määrätyllä alueella saattaa vaikuttaa siihen, millaiseksi roolijako jollakin toisella alueella muodostuu «, todentuu $\mathrm{mm}$. siinä, että perheissä, joissa vaimo on ansiotyössä, mies osallistuu lasten sosiaalisaation ohjaamiseen, lasten kontrolloimiseen ja perheen taloustoimiin enemmän kuin kotirouvaperheissä (Eskola, 90-94). Blood ja Wolfe tarjoavat tälle omassa tutkimuksessaankin löytämälle vaimon ansiotyön ja kumppanuuden voimistumisen yhteydelle selityksen: työpaineen kasvaessa vapaampi puoliso joutuu hoitamaan uusia tehtäviä, ja sentähden aviomies joutuu osallistumaan usein vaimon traditionaalisiin tehtäviin, jos tämä käy ansiotyössä (Blood-Wolfe, 62, 65). ${ }^{1}$

Kotipiirin työpaineen tasoittumisen voi aikaansaada "organisaation itsesäätelykyky " tai mahdollisesti ansiotyö nostaa vaimon arvovaltaa ja tämä vuorostaan selittää, miksi mies 'joutuu' enemmän osallistumaan vaimolle traditionaalisesti kuuluviin kotitoimiin. Wolfe on viitannut eräässä yhteydessä siihen, että ansiotyö, antaessaan vaimolle riippumattomuutta ja kehittäessään erilaisia taitoja ja tietoja, nostaa hänen arvovaltaansa perheessä (Wolfe, 109).

Vaimon ansiotyöllä aviopuolisoitten kumppanuutta lisäävänä tekijänä voi näin ollen olla myös funktionaalisia, perheen kiinteyttä edistäviä seuraamuksia. Voidaan olettaa, että etenkin sellainen ansiotyö, mitä tehdään perhekohtaisista syistä, esim. perheen toimeentulon turvaamiseksi, on yhteydessä kumppanuuteen: näissä perheissä kumppanuus on yleisempää kuin niissä perheissä, joissa vaimot käyvät ansiotyössä enemmän henkilökohtaisista syistä.

Haastattelussa tiedusteltiin aviovaimoilta pääasiallisinta syytä ansiotyössä käyntiin. Tutkimuksen ylemmässä yhteiskuntaluokassa $72 \%$ ja alemmassa luokassa $93 \%$ ansioäideistä mainitsee ensi sijassa taloudellisen motiivin ansiotyölleen. ${ }^{2}$ Kuten seuraavasta asetelmasta havaitaan, kump-

1 Myös Mildred Weil on todennut, että vaimon ollessa ansiotyössä eikä kotirouvana mies auttaa enemmän kodin- ja lastenhoitotehtävissä (Weil, 93).

2 Haastateltavat luokiteltiin miehen ammatin perusteella kolmeen yhteiskunta- 
panuus on kodinhoidon alalla ${ }^{1}$ selvästi yleisempää hypoteesin mukaisesti juuri taloudellisista syistä ansiotyössä käyvien vaimojen perheissä.

\section{Ansio ty össä \\ taloudellisista muista syistä syistä}

Kumppanuus yleistä

\begin{tabular}{lr}
43 & 16 \\
43 & 46 \\
14 & 38 \\
\hline $100 \%$ & $100 \%$
\end{tabular}

Kumppanuus vähäistä

$$
\chi^{2}=15.63 ; \mathrm{P}<.001
$$

(Erot ovat tilastollisesti merkitseviä myös ylemmässä luokassa, jossa riittää 'tapauksia' kumpaankin luokkaan: $\chi^{2}=8.25 ; \mathrm{P}<.02$ )

Perheen taloudellisesta toimeentulosta ja kodinhoitoon kuuluvista tehtävistä huolehtiminen sekä lisäksi lasten kasvatus, lasten sosialisaation ohjaaminen, ovat nykyperheen keskeisiä toimialoja. Lasten sosialisaation alalla esiintyvää aviopuolisoitten yhteisosallistumista, kasvatuskumppanuutta, mittaamaan käytetään asteikkoa (toisintokerroin 0.93), joka koostuu seuraavista kysymyksistä:

luokkaan: ylin luokka, keskiluokka, työväestö. Miten tämä jako vastaa haastateltavien itsensä kokemaa luokkatietoisuutta ilmenee seuraavasta:

Katsotaan ammatin perusteella kuuluvan

Katsoo itse kuuluvansa ylimpään luokkaan keskiluokkaan

työväestöön

$\begin{array}{ll}\text { - ylimpään luokkaan } \ldots \ldots \ldots \ldots & 11 \% \\ \text { - keskiluokkaan } & 8 . \ldots \ldots \ldots\end{array}$

- työväestöön ................ 1 \%

- ei osaa sanoa ............... $4 \%$

$\begin{array}{rr}-69 \% & -16 \% \\ 27 \% & 80 \% \\ 4 \% & 4 \%\end{array}$

Huom. Analyysissä käytetään pääasiassa jakoa ylempi luokka (=ylin luokka ja keskiluokka) ja alempi luokka (=työväestö).

1 Kodinhoitokumppanuutta koskeva asteikko (toisintokerroin 0.93), josta Eskola käyttää nimitystä smiehen osallistuminen taloustöihin> koostuu seuraavista kysymyksistä (Eskola, 93-94):

1. Auttaako miehenne Teitä talousaskareissa?

2. Milloin miehenne viimeksi auttoi Teitä astioiden pesussa tai ruuanvalmistuksessa?

3. Miten usein miehenne auttaa Teitä ruokaostosten suorittamisessa?

4. Milloin viimeksi miehenne auttoi Teitä pyykinpesussa?

5. Milloin viimeksi miehenne auttoi Teitä siivouksessa?

$\begin{array}{ll}\begin{array}{l}\text { Auttaa } \\ + \\ \begin{array}{l}\text { Enintään puoli } \\ \text { vuotta sitten } \\ +\end{array}\end{array} & \begin{array}{l}\text { Yi auta puoli vuotta } \\ \text { sitten }\end{array} \\ \begin{array}{l}\text { Ainakin joskus } \\ +\end{array} & \text { Ei koskaan } \\ \begin{array}{l}\text { Enintään kolme } \\ \text { kuukautta sitten } \\ +\end{array} & \begin{array}{l}\text { Yli kolme kuu- } \\ \text { kautta sitten }\end{array} \\ \begin{array}{l}\text { Eilen tai toissa- } \\ \text { päivänä }\end{array} & \begin{array}{l}\text { Pari päivää sit- } \\ \text { ten tai enemmän }\end{array}\end{array}$


Taulu 1. Vaimon ansiotyössä käynti ja aviopuolisoiden kumppanuus lastenkasvatuksessa eri yhteiskuntaluokissa.

$T a b l e$ 1. The wife's wage-earning activity and the spouses' companionship in the education of children, by social classes.

\begin{tabular}{|c|c|c|c|c|}
\hline \multirow[b]{2}{*}{$\begin{array}{l}\text { Lastenkasvatus }- \\
\text { Education of children }\end{array}$} & \multicolumn{2}{|c|}{$\begin{array}{l}\text { Ylempi luokka } \\
\text { Higher class }\end{array}$} & \multicolumn{2}{|c|}{$\begin{array}{l}\text { Alempi luokka } \\
\text { Lower class }\end{array}$} \\
\hline & $\begin{array}{l}\text { Vaimo ansio- } \\
\text { työssä - } \\
\text { Wife engaged } \\
\text { in wage- } \\
\text { earning work }\end{array}$ & $\begin{array}{l}\text { Vaimo } \\
\text { kotona- } \\
\text { Wife staying } \\
\text { at home }\end{array}$ & $\begin{array}{l}\text { Vaimo ansio- } \\
\text { työssä - } \\
\text { Wife engaged } \\
\text { in wage- } \\
\text { earning work }\end{array}$ & $\begin{array}{l}\text { Vaimo } \\
\text { kotona - } \\
\text { Wife staying } \\
\text { at home }\end{array}$ \\
\hline \multirow{3}{*}{$\begin{array}{l}\text { Kumppanuus yleistä }- \\
\text { Companionship extensive .... }\end{array}$} & (112) & (127) & $(100)$ & (115) \\
\hline & 30 & 17 & 35 & 22 \\
\hline & 42 & 45 & 37 & 53 \\
\hline \multirow{3}{*}{$\begin{array}{l}\text { Kumppanuus vähäistä - } \\
\text { Companionship limited } \ldots .\end{array}$} & 28 & 38 & 28 & 25 \\
\hline & $100 \%$ & $100 \%$ & $100 \%$ & $100 \%$ \\
\hline & $\chi^{2}=7.17$ & $; \mathrm{P}<.05$ & $\chi^{2}=6.5$ & $55 ; \mathrm{P}<.05$ \\
\hline
\end{tabular}

1. Kumpi pääasiassa valvoo lastenne läksyjenlukua?

2. Kumpi perheessänne enimmäkseen seuraa, kenen kanssa lapsenne leikkivät?

3. Kumpi perheessänne pääasiassa opettaa lapsille käytöstapoja?

Molemmat

yhtä paljon

Pääasiassa

toinen

Taulusta 1 nähdään, että ansiotyössä käynnin kumppanuutta lisäävä vaikutus ulottuu myös lasten kasvatukseen. Kummassakin miehen ammatin mukaan määritellyssä yhteiskuntaluokassa lastenkasvatuskumppanuus. on ansioäitiperheissä yleisempää kuin kotirouvaperheissä.

Toistaiseksi tarkastelun kohteena olleet perheen toimialat: kodinhoito, ansiotyö ja lasten kasvatus, kuuluvat perheen välttämättömiin tehtäviin. Tässä mielessä niitä voidaan pitää perheen eksternaaliseen järjestelmään kuuluvina, sillä tämä järjestelmä Homansin mukaan huolehtii siitä, «miten ryhmä säilyy ympäristössään " (Homans, 90, 107). Perheen eksternaalisessa: järjestelmässä aviopuolisoitten yhteisosallistuminen osoittautuu kasautuvaksi - samoin kumppanuuden puute. Taulussa 2 sivulla 84 voidaan nimittäin todeta, että kummassakin yhteiskuntaluokassa kodinhoito- ja lastenkasvatuskumppanuuden välillä on myös riippuvuutta. Perusaineistosta päätellen tämä riippuvuus on suunnaltaan positiivista: kumppanuus. 
Taulu 2. Aviopuolisoiden kumppanuuden kasautuminen eri yhteiskuntaluokissa.

Table 2. The cumulation of the spouses' companionship, by social classes.

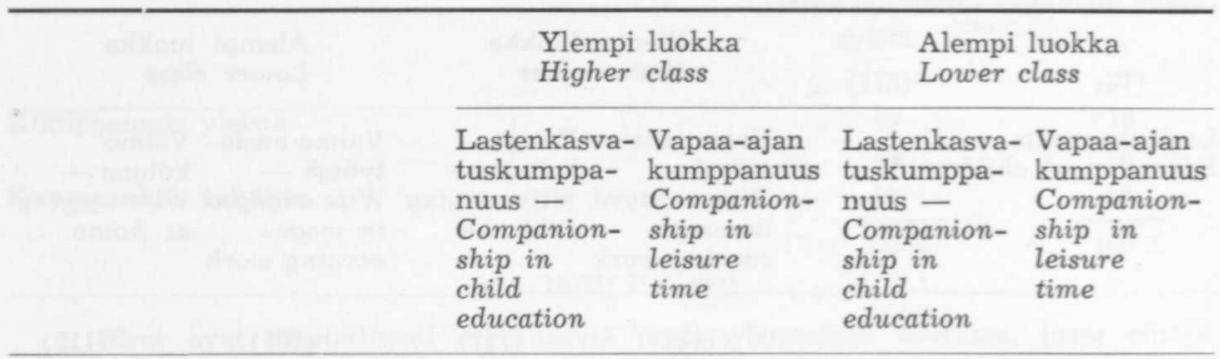

Kodinhoitokumppanuus

Companionship in housekeeping

0.19

0.07

0.23

0.16

Lastenkasvatuskumppanuus -

Companionship in child education

0.15

0.14

Riippuvuuden voimakkuuden ilmaisijana on käytetty kontingenssikerrointa, jonka maksimiarvo 3-luokkaisilla muuttujilla on 0.81 (Walker, 287).

For indicating the degree of interdependence a contingency coefficient is used whose maximum value in the three-class variable here in question is 0.81 .

$$
\begin{array}{ll}
\mathrm{C}<0.16 ; & \mathrm{P}>.10 \\
\mathrm{C}=0.19 ; & \mathrm{P}<.10 \\
\mathrm{C}=0.22 ; & \mathrm{P}<.05
\end{array}
$$

kasautuu, samoin kumppanuuden puute. Aviopuolisoiden vapaa-ajan käyttö ajanvietteiden ja harrastusten parissa ei kuulu enää «perheen välttämättömiin tehtäviin « ja niinmuodoin ei myöskään perheen eksternaaliseen järjestelmään. Kumppanuutta esiintyy luonnollisesti myös tällä alueella, mutta onko se riippumaton kotitoimiin liittyvästä kumppanuudesta? Homansin erään hypoteesin mukaan on odotettavissa, että kumppanuus ulottuu perhetoimien ulkopuolellekin vapaa-ajan käytön alueelle:

„Jos ryhmän jäsenten vuorovaikutus eksternaalisessa järjestelmässä on vilkasta, jäsenet mieltyvät toisiinsa ja tämä aikaansaa vuorovaikutuksen ulottumisen eksternaalisen järjestelmän vaatiman vuorovaikutuksen yli, (Homans, 112, 134).

Aviopuolisoiden 'vapaaehtoista' yhteisosallistumista vapaa-ajan käytön alueella mittaava asteikko koostuu seuraavista kysymyksistä:

1. Mitä yhteisiä harrastuksia Teillä on?

Vähintään

3 yhteistä

harrastusta
Korkeintaan

2 yhteistä

harrastusta 
Taulu 3. Vaimon ansiotyössä käynti ja aviopuolisoiden vapaa-ajan kumppanuus eri yhteiskuntaluokissa.

Table 3. The wife's wage-earning activity and the spouses' companionship in leisure time, by social classes.

\begin{tabular}{|c|c|c|c|c|}
\hline \multirow[b]{2}{*}{$\begin{array}{l}\text { Vapaa-ajan käyttö } \\
\text { Use of leisure time }\end{array}$} & \multicolumn{2}{|c|}{$\begin{array}{l}\text { Ylempi luokka } \\
\text { Higher class }\end{array}$} & \multicolumn{2}{|c|}{$\begin{array}{l}\text { Alempi luokka } \\
\text { Lower class }\end{array}$} \\
\hline & $\begin{array}{l}\text { Vaimo ansio- } \\
\text { työssä - } \\
\text { Wife engaged } \\
\text { in wage- } \\
\text { earning } \\
\text { work }\end{array}$ & $\begin{array}{l}\text { Vaimo } \\
\text { kotona - } \\
\text { Wife staying } \\
\text { at home }\end{array}$ & $\begin{array}{l}\text { Vaimo ansio- } \\
\text { työssä - } \\
\text { Wife engaged } \\
\text { in wage- } \\
\text { earning } \\
\text { work }\end{array}$ & $\begin{array}{l}\text { Vaimo } \\
\text { kotona - } \\
\text { Wife staying } \\
\text { at home }\end{array}$ \\
\hline & (112) & (127) & (100) & (115) \\
\hline $\begin{array}{l}\text { Kumppanuus yleistä } \\
\text { Companionship extensive .... }\end{array}$ & 30 & 36 & 41 & 34 \\
\hline & 42 & 40 & 45 & 42 \\
\hline $\begin{array}{l}\text { Kumppanuus vähäistä } \\
\text { Companionship limited } \\
\text { Tieto puuttuu } \\
\text { No data available } \ldots \ldots \ldots \ldots . .\end{array}$ & $\begin{array}{l}27 \\
1\end{array}$ & $\begin{array}{l}24 \\
-\end{array}$ & $\begin{array}{l}14 \\
-\end{array}$ & $\begin{array}{r}22 \\
2\end{array}$ \\
\hline & $\begin{array}{c}100 \% \\
\chi^{2}=0.89 ; \mathrm{P}\end{array}$ & $\begin{aligned} & 100 \% \\
P> & .10\end{aligned}$ & $\begin{array}{c}100 \% \\
\chi^{2}=2.5 \varepsilon\end{array}$ & $\begin{array}{r}100 \% \\
8 ; \mathrm{P}>.10\end{array}$ \\
\hline
\end{tabular}

2. Kun menette teatteriin, elokuviin tms., on miehenne mukananne 1) aina 2) useimmiten 3) harvoin 4) ei koskaan

3. Kuuluuko perheenne ystäväpiiriin enimmäkseen 1) Teidän 2) miehenne 3) tasapuolisesti molempien 4) pääasiassa yhteisiä ystäviä

4. Keskusteletteko miehenne kanssa yhteiskunnallisista kysymyksistä?
Aina

Harvemmin

Molempien

ja yhteisiä

ystäviä

$\underset{\text { Kyllä }}{+}$
Vain toisen

ystäviä

$\overline{-}$

Asteikon toistettavuuskerroin on 0.92 . Asteikon rakenteellisena puutteena on $\mathrm{mm}$. se, että 1. ja 2. kysymys eivät ole täysin riippumattomia toisistaan. Asteikkoa on analyysissa kuitenkin käytetty kolmiluokkaisena tavalla, mikä poistaa virhemahdollisuuden.

Vapaa-ajan käyttötapojen asteikollisuus osoittaa, että kumppanuus ja sen puute esiintyvät kasautuvasti myös vapaa-ajan käytössä.

Homansin hypoteesi kumppanuuden leviämisestä eksternaalisen järjestelmän yli ei saa aivan kiistatonta tukea, joskohta tulokset eivät myöskään kumoa hypoteesia (taulu 2). 
Perusaineiston jakautumat ovat yleensä Homansin hypoteesin suuntaiset, mutta riippuvuus on tilastollisesti epävarma. Kun tarkastellaan vaimon ansiotyössä käynnin ja vapaa-ajan kumppanuuden yhteyttä (tau$l u 3$ ), on havaittavissa hypoteesin suuntaista riippuvuutta vain alemman yhteiskuntaluokan kohdalla.

Hypoteesin koettelemiseksi tutkittiin vielä kumppanuuden esiintymistä poliittisen käyttäytymisen ja kotitoimien välillä. Riippuvuutta esiintyi ainoastaan alemmassa yhteiskuntaluokassa eli työväestön parissa, jossa ne vaimot äänestivät yleisemmin 'viime vaaleissa' samaa puoluetta kuin miehensä, joiden perheissä esiintyi myös lastenkasvatus- ja kodinhoitokumppanuutta:

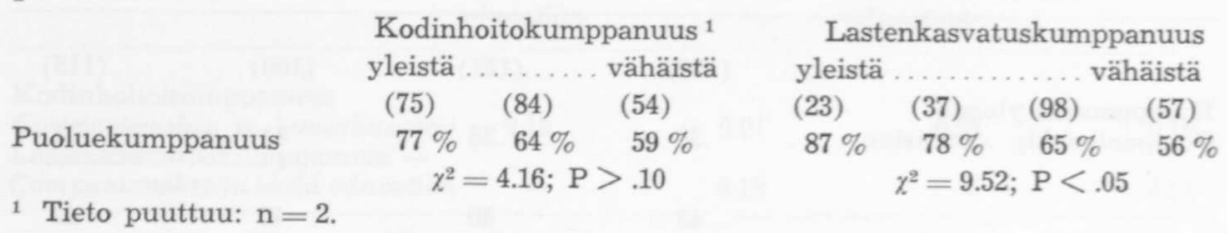

Aviopuolisoiden kumppanuudella on taipumus levittäytyä, samoin kumppanuuden puutteella. Tutkimustulokset viittaavat lisäksi siihen, että työväenluokassa kumppanuus esiintyy inklusiivisempana kuin ylemmässä luokassa, kattaen perheen välttämättömien toimien lisäksi myös aviopuolisoitten vapaa-ajan käytön. Ylemmässä luokassa kumppanuus ei esiinny yhtä laajaulotteisena, vaan kumppanuus vapaa-ajan käytössä on riippumattomampi kotitoimiin liittyvästä yhteisosallistumisesta.

Bloodin ja Wolfin havainnot tukevat yleispäätelmää kumppanuuden tai sen puutteen kasautuvasta luonteesta: jos aviopuolisot osallistuvat yhdessä esim. yhdistystoimintaan, niin heillä usein on myös yhteisiä ystäviä ja he jakavat työkokemuksiaan keskenään mm. siten, että mies kertoo työasioitaan usein vaimolleen. Sitävastoin jos sanotunlaista kumppanuutta ei yhdellä alalla esiinny, sitä ei silloin tavallisesti esiinny toisillakaan aloilla. (Blood \& Wolfe, 151-154).

\subsection{Kumppanuden vaihtelu}

Käytettävissä oleva tutkimusaineisto antaa mahdollisuuden tiedustella sellaisia sosiaalisia tekijöitä, jotka ovat yhteydessä aviopuolisoitten kumppanuuden vaihteluihin. Tällaisena tekijänä voidaan pitää jo aikaisemmin mainittua vaimon ansiotyössä käyntiä, jos sitä käytetään riippumattomana muuttujana.

Taulussa 4 näkyvät tutkimuksen kumppanuusmuuttujien jakautumat yhteiskuntaluokittain. Kumppanuus esiintyy kodinhoidon ja lasten kasvatuksen aloilla jonkin verran yleisempänä työväestön keskuudessa kuin muissa yhteiskuntaluokissa. Tulos viittaa siihen, että työväestön keskuu- 
Taulu 4. Aviopuolisoiden kumppanuus eri yhteiskuntaluokissa.

Table 4. The spouses' companionship, by social classes.

\begin{tabular}{|c|c|c|c|}
\hline & $\begin{array}{l}\text { Ylin luokka } \\
\text { Upper class }\end{array}$ & $\begin{array}{l}\text { Keskiluokka } \\
\text { Middle class }\end{array}$ & $\begin{array}{l}\text { Työväestö } \\
\text { Working-class } \\
\text { population }\end{array}$ \\
\hline \multirow{3}{*}{$\begin{array}{l}\text { Kodinhoito - Housekeeping } \\
\text { kumppanuus yleistä } \\
\text { companionship extensive }\end{array}$} & (72) & (167) & (215) \\
\hline & 14 & 25 & 35 \\
\hline & 49 & 50 & 39 \\
\hline \multirow{4}{*}{$\begin{array}{l}\text { kumppanuus vähäistä } \\
\text { companionship limited } \ldots \ldots \ldots \ldots \\
\text { tieto puutuu } \\
\text { no data available } \ldots \ldots \ldots \ldots \ldots \ldots\end{array}$} & 37 & 25 & 25 \\
\hline & - & - & 1 \\
\hline & $100 \%$ & $100 \%$ & $100 \%$ \\
\hline & $\chi^{2}$ & $16.30 ; \mathrm{P}<.01$ & \\
\hline
\end{tabular}

Lastenkasvatus - Child education

kumppanuus yleistä

companionship extensive $\quad \ldots \ldots . \quad 22$

$\begin{array}{lll}22 & 23 & 28\end{array}$

$\begin{array}{lll}39 & 46 & 46\end{array}$

kumppanuus vähäistä

$39 \quad 31 \quad 26$

$100 \% \quad 100 \% \quad 100 \%$

$\chi^{2}=4.29 ; \mathrm{P}>.10$

Vapaa-ajan käyttö - Use of leisure time

kumppanuus yleistä

companionship extensive ........ 38

$38 \quad 32 \quad 37$

$\begin{array}{lll}40 & 41 & 44\end{array}$

kumppanuus vähäistä

companionship limited ........... 22

$\begin{array}{lll}22 & 27 & 18\end{array}$

tieto puutuu

- 1

$100 \% \quad 100 \% \quad 100 \%$

$\chi^{2}=3.92 ; \mathrm{P}>.10$

dessa vaimon ja miehen roolit ovat vähemmän differentioituneet kuin muissa yhteiskuntaluokissa (vrt. Kohn-Carrol, 382, 390). Vapaa-ajan kumppanuudessa ei sitävastoin eri yhteiskuntaluokkien välillä esiinny huomionarvoisia eroja. Tämä johtuu kuitenkin osittain käytetyn asteikon sensitiivisyyden puutteesta, sillä jos tarkastellaan vapaa-ajan kumppanuutta yksityisten käyttötapojen pohjalta, havaitaan eroja eri yhteiskuntaluokkien välillä (ks. taulu 5). Näistä eroista on kuitenkin vaikea johtaa mitään yleistä säännönmukaisuutta. 
Taulu 5. Aviopuolisoiden kumppanuus vapaa-ajan eri aloilla yhteiskuntaluokittain.

Table 5. The spouses' companionship in different fields of leisure activity, by social classes.

\begin{tabular}{|c|c|c|c|}
\hline & $\begin{array}{l}\text { Ylin luokka } \\
\text { Upper class }\end{array}$ & $\begin{array}{l}\text { Keskiluokka } \\
\text { Middle class }\end{array}$ & $\begin{array}{l}\text { Työväestö } \\
\text { Working-class } \\
\text { population }\end{array}$ \\
\hline $\begin{array}{l}\text { Mennään teatteriin ja elokuviin } \\
\text { useimmiten yhdessä } \\
\text { Most theatre and cinema visits made } \\
\text { jointly } \ldots \ldots \ldots \ldots \ldots \ldots \ldots \ldots \ldots \ldots \ldots \ldots\end{array}$ & (72) & (167) & (215) \\
\hline
\end{tabular}

Vähintään kaksi yhteistä harrastusta At least two interests in common ....

$58 \%$

$51 \%$

$27 \%$

$\chi^{2}=32.06 ; \mathrm{P}<.001$

Keskustellaan yhteiskunnallisista

kysymyksistä

Discussions on social questions .......

$31 \%$

$41 \%$

$43 \%$

$\chi^{2}=3.60 ; \mathrm{P}>.10$

Ystävät pääasiassa yhteisiä

Friends principally common

$74 \%$

$74 \%$

$80 \%$

$\chi^{2}=2.72 ; \mathrm{P}>.10$

Avioliitossa tapahtuu ajanmittaan tehtävien osittumista ja roolien eriytymistä, joilla on merkityksensä myös kumppanuuden kannalta. Vastaavioituneiden rooliodotukset ovat enemmän tai vähemmän epämääräiset, diffuusit; roolien eriytyminen ja velvollisuuksien jakaantuminen jäsentyvät selvästi vasta myöhemmin avioliiton sopeutumisvuosien kuluessa. Perinteellinen, 'luontainen' roolijako ei ole urbaanisissa avioliitoissa yhtä selvä ja opastusta antava kuin maaseudun avioliitoissa. Jos nuoremmissa urbaanisissa avioliitoissa roolit ovat eriytymättömämpiä kuin vanhemmissa avioliitoissa, tästä seuraa samalla, että nuoremmissa avioliitoissa kumppanuus on yleisempää kuin vanhemmissa.

Taulussa 6 on avioliiton kestoajan osoittimena käytetty vaimon ikää. Voidaan havaita, että vanhimmassa luokassa kumppanuus on hypoteesin mukaisesti vähäisintä. Sitävastoin erot kahden nuoremman luokan välillä ovat vähäiset. Huomattavin poikkeus hypoteesista esiintyy ylemmän luokan vapaa-ajan kumppanuuden kohdalla.

Blood ja Wolfe ovat myös todenneet, että kumppanuus vähenee ajan mukana. Heidän selityksensä mukaan vanhemmissa avioliitoissa aviopuoli- 
T a ulu 6. Aviopuolisoiden kumppanuus vaimon iän mukaan eri yhteiskuntaluokissa.

Table 6. The spouses' companionship according to the wife's age, by social classes.

\begin{tabular}{|c|c|c|c|c|c|c|}
\hline & \multicolumn{3}{|c|}{$\begin{array}{l}\text { Ylempi luokka } \\
\text { Higher class }\end{array}$} & \multicolumn{3}{|c|}{$\begin{array}{l}\text { Alempi luokka } \\
\text { Lawer class }\end{array}$} \\
\hline & \multicolumn{3}{|c|}{ Ikä, v. } & \multicolumn{3}{|c|}{ Age, $y$. } \\
\hline & -34 & $35-44$ & $45-$ & -34 & $35-44$ & $45-$ \\
\hline \multirow{2}{*}{$\begin{array}{l}\text { Kodinhoito - Housekeeping } \\
\text { kumppanuus yleistä } \\
\text { companionship extensive }\end{array}$} & $g$ & $(120)$ & (38) & (73) & (115) & $(27)$ \\
\hline & 33 & 17 & 10 & 34 & 40 & 15 \\
\hline \multirow{5}{*}{$\begin{array}{l}\text { kumppanuus vähäistä } \\
\text { companionship limited } \\
\text { tieto puuttuu } \\
\text { no data available }\end{array}$} & 48 & 53 & 45 & 40 & 39 & 37 \\
\hline & 19 & 30 & 45 & 25 & 21 & 44 \\
\hline & - & - & - & 1 & - & 4 \\
\hline & $100 \%$ & $100 \%$ & $100 \%$ & $100 \%$ & $100 \%$ & $100 \%$ \\
\hline & \multicolumn{3}{|c|}{$\chi^{2}=15.76 ; \mathrm{P}<.01$} & \multicolumn{3}{|c|}{$\chi^{2}=9.05 ; \mathrm{P}<.10$} \\
\hline
\end{tabular}

\begin{tabular}{lcccccc}
$\begin{array}{l}\text { Lastenkasvatus - Child } \\
\text { education } \\
\text { kumppanuus yleistä } \\
\text { companionship extensive }\end{array}$ & 22 & 26 & 16 & 29 & 29 & 22 \\
& 47 & 43 & 37 & 46 & 48 & 33 \\
$\begin{array}{l}\text { kumppanuus vähäistä } \\
\text { companionship limited }\end{array}$ & 31 & 31 & 47 & 25 & 23 & 45 \\
\hline & $100 \%$ & $100 \%$ & $100 \%$ & $100 \%$ & $100 \%$ & $100 \%$ \\
& & $\chi^{2}=4.48 ; \mathrm{P}>.10$ & & $\chi^{2}=5.17 ; \mathrm{P}>.10$
\end{tabular}

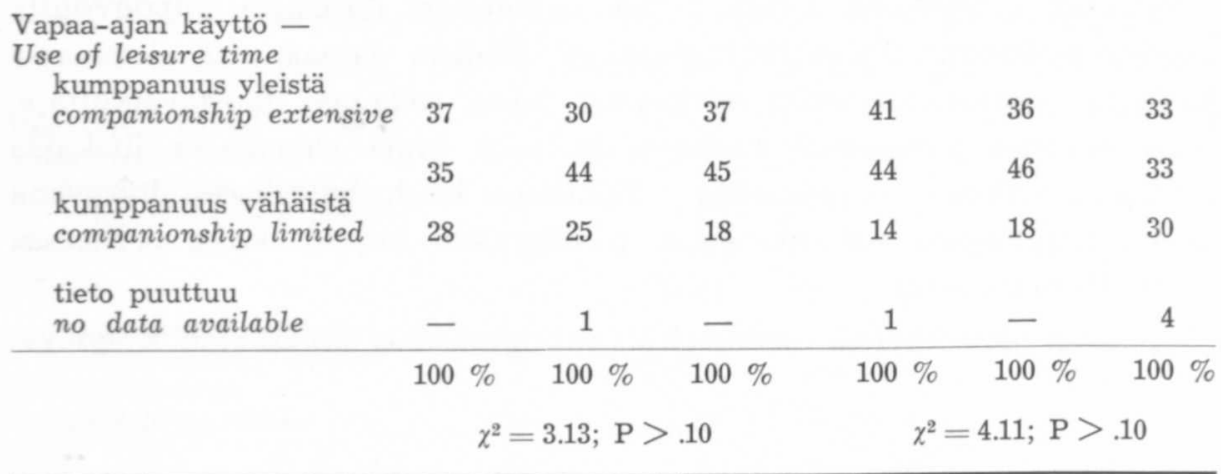

soitten ei tarvitse enää todistaa kiintymystään yhteisosallistumisen avulla, vaan kumpikin aviopuoliso voi itsenäisesti toimien kantaa kortensa yhteiseen kekoon: «avioliitto voi nyt olla symbioottinen olematta synkronisoitunut koko ajan « (70—73). Tämäkin selitys viittaa aviopuolisoitten roolien 
differentioitumiseen avioliiton myöhemmässä vaiheessa, mikä samalla merkitsee kumppanuuden heikkenemistä siinä mielessä, kuin se on tässä tutkimuksessa määritelty.

Useissa tutkimuksissa on todettu, että aviopuolison valinnan kriteerinä samankaltaisuus sosiaalisessa taustassa ja persoonallisuuden piirteissä esiintyy yleisemmin kuin sattuman perusteella olisi odotettavissa. Nuoret avioituvat mieluimmin kaltaistensa kanssa: "like to mate with like * (Burgess-Wallin, 204-209). Edelleen on todettu, että aviopuolisoiden samankaltaisuuteen perustuvat homogamiset avioliitot johtavat harvemmin avioeroon kuin heterogamiset avioliitot (Goode, 97-101). Homogamisuuden merkitystä aviollisen sopeutuvuuden edellytyksenä tähdentää myös Margaret Mead: «Jos aviopuolisot eroavat yhteiskuntaluokan, asuinseutunsa, kansallisuutensa ja uskontonsa puolesta toisistaan, saattaa pienenkin ratkaisun tekeminen, jonka pitäisi olla vain yksi lanka uuden elämän kudoksessa, sekoittaa koko kudoksen * (Mead, 346-347). Heider on pelkistänyt ajatuksen seuraaviin väitteisiin: $\mathrm{P}$ similar to $\mathrm{O}$ induces $\mathrm{P}$ likes $\mathrm{O}$, or P tends to like a similar O, eli yhtäläisyys aikaansaa mieltymystä tai henkilö on taipuvainen mieltymään yhtäläiseen henkilöön (Heider, 184). Homansin mukaan mieltymys vuorostaan aikaasaa vuorovaikutuksen lisääntymisen, ja nyt voidaankin olettaa, että aviopuolisoitten sosiaalisen taustan samankaltaisuus on omiaan edistämään kumppanuutta.

Tutkimusaineiston rajoittuneisuus antaa mahdollisuuden koetella hypoteesia lähinnä aviopuolisoitten koulusivistyksen suhteen.

Taulun 7 tosiasiat antavat kuitenkin varsin vähän tukea hypoteesille. Lähinnä vain alemmassa yhteiskuntaluokassa jakautumat seuraavat hypoteesin suuntaa: kumppanuus on yleisempää koulusivistyksen suhteen homogamisissa avioliitoissa kuin heterogamisissa avioliitoissa.

Eräänä selityksenä siihen, ettei hypoteesin mukaista riippuvuutta esiinny molemmissa yhteiskuntaluokissa, voidaan olettaa, että alemmassa luokassa koulusivistykseen kytkeytyy jokin sellainen taustavaikuttaja, joka puuttuu ylemmässä luokassa ja joka juuri alemmassa luokassa aiheuttaa todettua riippuvuutta. Tällaisena koulusivistykseen liittyvänä taustavaikuttajana voi olla esim. päätösvallan käyttö: kuka perheessä päättää eri asioista.

Päätösvallan käyttöä tiedusteltiin tutkimuksessa seuraavien kysymysten avulla:

\section{Vapaa-ajan käytöstä päättäminen}

1. Kuuluuko perheenne ystäväpiiriin enimmäkseen Teidän, miehenne tai molempien ystäviä?

2. Päättäessänne lähteä yhdessä miehenne kanssa teatteriin, elokuviin tms. onko niin, että useimmiten 1) Te päätätte, mihin menette, 2) miehenne päättää, mihin menette, 3 ) yhdessä päätätte? 
Taulu 7. Aviopuolisoiden kumppanuus suhteellisen koulusivistyksen mukaan eri yhteiskuntaluokissa.

$T a b l e$ 7. The spouses' companionship according to relative educational level, by social classes.

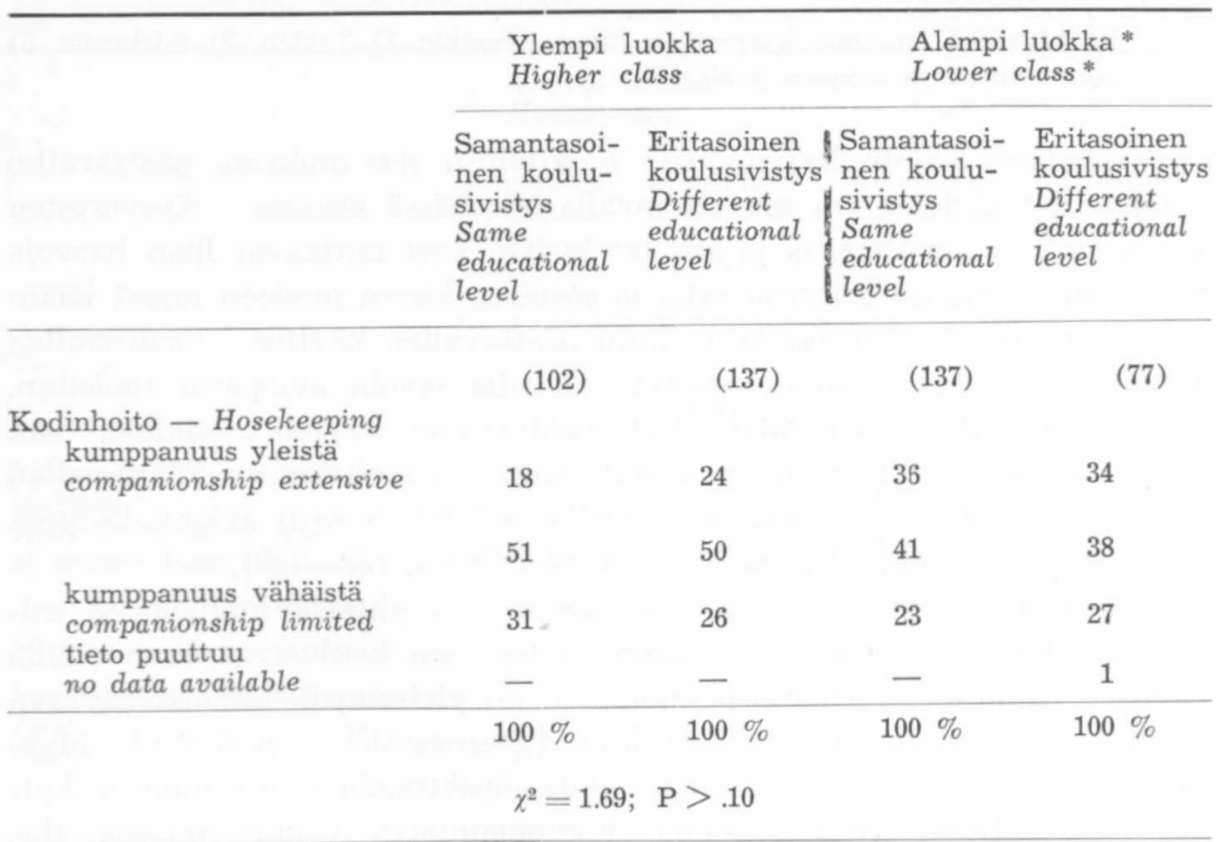

Lastenkasvatus - Child education

kumppanuus yleistä

companionship extensive

$\begin{array}{llll}24 & 23 & 29 & 27\end{array}$

$\begin{array}{llll}43 & 44 & 45 & 46\end{array}$

kumppanuus vähäistä companionship limited

$\begin{array}{cccc}33 & 33 & 26 & 27 \\ 100 \% & 100 \% & 100 \% & 100 \%\end{array}$

\begin{tabular}{lcccc}
$\begin{array}{l}\text { Vapaa-ajan käyttö - Use of } \\
\text { leisure time } \\
\begin{array}{l}\text { kumppanuus yleistä } \\
\text { companionship extensive }\end{array}\end{array}$ & 31 & 35 & 41 & 29 \\
$\begin{array}{l}\text { kumppanuus vähäistä } \\
\text { companionship limited } \\
\text { tieto puuttuu }\end{array}$ & 46 & 37 & 43 & 45 \\
no data available & 22 & 28 & 15 & 25 \\
& 1 & - & 1 & 1 \\
\hline & $100 \%$ & $100 \%$ & $100 \%$ & $100 \%$
\end{tabular}

* Tieto koulusivistyksestä puuttuu: $\mathrm{n}=1$. - No data available as to educational level: $n=1$. 


\section{Talousasioista päättäminen}

Kun Teille tai miehellenne hankitaan jokin uusi vaatekappale, kumpi ostoksesta päättää?

\section{Luvan antaminen lapsille}

Kääntyvätkö lapsenne kysyessään lupaa johonkin 1) Teidän, 2) miehenne, 3) tasapuolisesti molempien puoleen?

Vastaukset näihin kysymyksiin luokiteltiin sen mukaan, päättävätkö aviopuolisot yhdessä vai muulla tavalla kyseisissä asioissa. Kysymysten validisuudessa on ilmeisiä puutteita: kysymykset mittaavat liian harvoja päätösvallan käytön erityisalueita, ja etenkin 'kenen puoleen lapset kääntyvät'-kysymys mittaa muutakin kuin päätösvallan käyttöä. Päätösvallan käyttö osoittautui muuten kytkeytyvän sillä tavoin avioparin rooleihin, ettei saatu syntymään mitään yleistä päätösvallan käytön asteikkoa, vaan oli turvauduttava yksityisiä osa-alueita kattaviin osoittimiin. Päätösvallan käytön jakautuminen noudattanee melko selväpiirteisesti aviopuolisoitten roolijakoa tehtävien hoitamisessa (vrt. Middleton, 122-123).

Taulusta 8 havaitaan, että vain alemmassa yhteiskuntaluokassa asioista päättämisen ja aviopuolisoitten suhteellisen koulusivistyksen välillä vallitsee riippuvuus: yhdessäpäättäminen on yleisempää koulusivistyksen suhteen homogamisissa perheissä kuin heterogamisissa perheissä. Myöhemmin seuraavassa tarkastelussa yhdessäpäättäminen osoittautuu kytkeytyvän selvästi aviopuolisoiden kumppanuuden voimistumiseen (ks. s. 93). Edellä todettiin, että koulusivistyksen suhteen homogamisissa perheissä kumppanuus esiintyi hypoteesin mukaisesti jonkin verran yleisempänä kuin heterogamisissa, mutta vain alemmassa yhteiskuntaluokassa. Tähän tarjoutuu nyt selitys: alemmassa yhteiskuntaluokassa aviopuolisoitten koulusivistyksen samantasoisuus aikaansaa sen, että asioista päätetään yhdessä, sitävastoin ylemmässä yhteiskuntaluokassa ei tämänkaltaista riippuvuutta esiinny. Yhdessäpäättäminen on yhteydessä vuorostaan kumppanuuden voimistumiseen, mikä juuri selittää alemmassa yhteiskuntaluokassa esiintyvän ja ylemmässä luokassa puuttuvan riippuvuuden.

Useat tutkimukset viittaavat siihen, että ryhmän jäsenten osallistuminen päätöksentekoon voimistaa jäsenten motivaatioita ja aikaansaa aktiivisuutta (ks. esim. Thibaut-Kelley, 283). Kurt Lewin on osoittanut moneen tutkimukseen viitaten, että ryhmäkeskusteluun ja ryhmäpäätökseen perustuva menetelmä on tehokkaampi kuin autoritaarinen johtamismenetelmä pyrittäessä aikaansaamaan muutoksia henkilöitten käyttäytymisessä ja tavoissa (Lewin, 287-296). Ryhmäpäätöksen tehokkuutta koskevissa selityksissä tähdennetään mm. sitä, että se lisää henkilökohtaista vastuuntunnetta ja samastumista asian kanssa.

Perheen päätösvallankäytön järjestelmää koskevissa tutkimuksissa erotetaan tavallisesti synkraattinen perhetyyppi edustamaan demokraattista vallankäyttöä: vaimo ja mies päättävät yhdessä asioista. Austraaliassa 
T a u lu 8. Yhdessäpäättämisen yleisyys eri toimialoilla ja aviopuolisoiden suhteellinen koulusivistys yhteiskuntaluokittain.

Table 8. The frequency of joint decisions made by the spouses in different fields of activity and the spouses' relative educational level, by social classes.

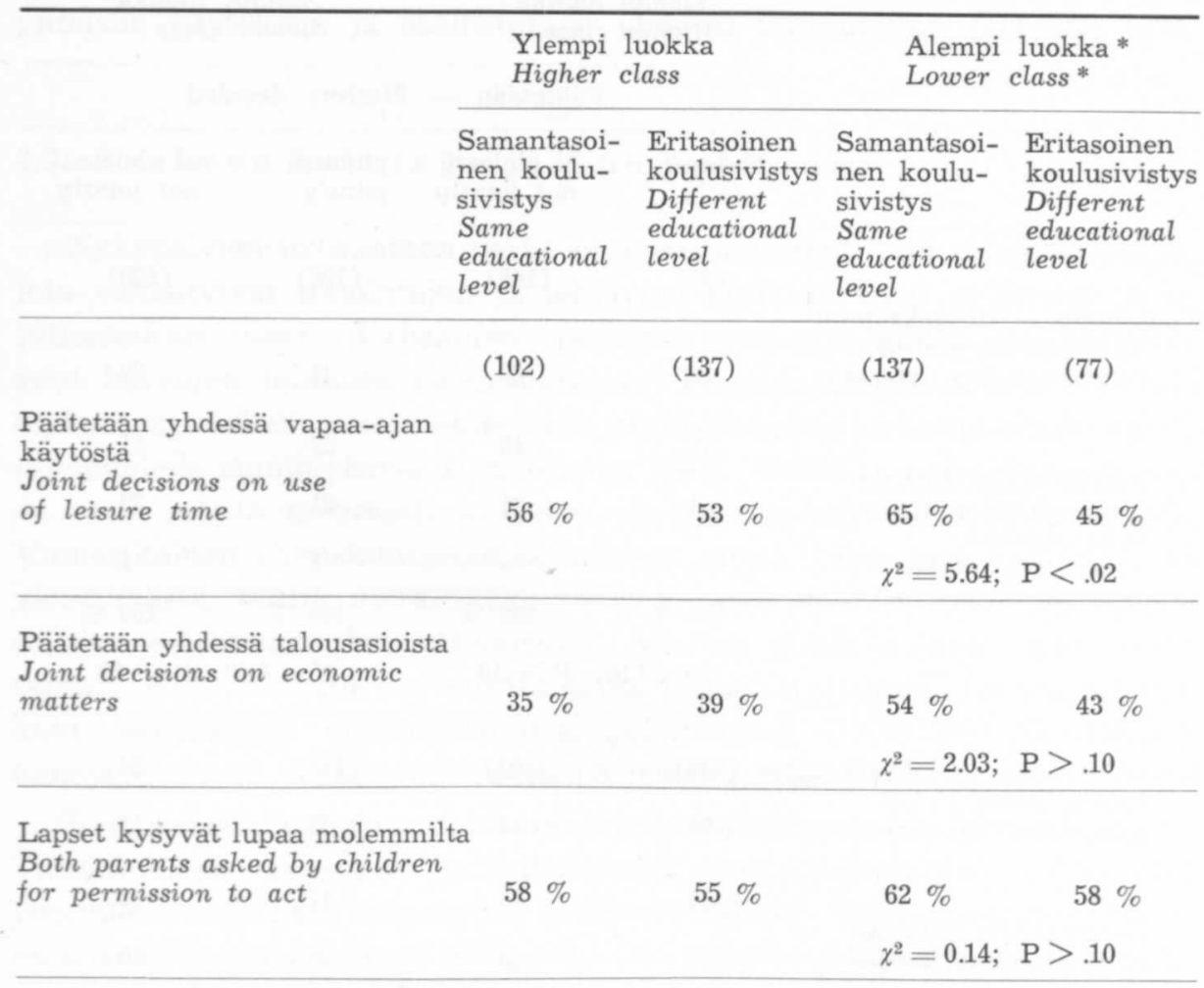

* Tieto koulusivistyksestä puuttuu: $\mathrm{n}=1$. - No data available as to educational level: $n=1$.

suoritetussa tutkimuksessa on havaittu, että jännitykset aviopuolisoiden välillä ovat keskimäärää matalammat synkraattisessa perheessä ja niissä perheissä korkeimmat, joissa esiintyy eniten aviopuolisoitten itsenäistä päättämistä (Herbst, 162, 166-167).

Nyt voidaankin olettaa, että synkraattisissa perheissä, joissa aviopuolisot päättävät yhdessä asioista, kumppanuus on yleisempää kuin ei-synkraattisissa perheissä.

Hypoteesi saa selvästi tukea taulun 9 jakaantumisesta. Yhdessäpäättäminen ja kumppanuus kytkeytyvät toisiinsa molemmissa yhteiskuntaluokissa, samoin niiden puute. Herbst on päätynyt tutkimuksessaan samansuuntaiseen tulokseen: yhteisten toimintojen ja yhteispäätösten lukumäärien välillä vallitsee positiivinen korrelaatio (Herbst, 162). Pidem- 
T a u lu 9. Aviopuolisoiden kumppanuus päätösvallan käytön mukaan eri yhteiskuntaluokissa.

Table 9. The spouses' companionship according to exercise of right of decision, by social classes.

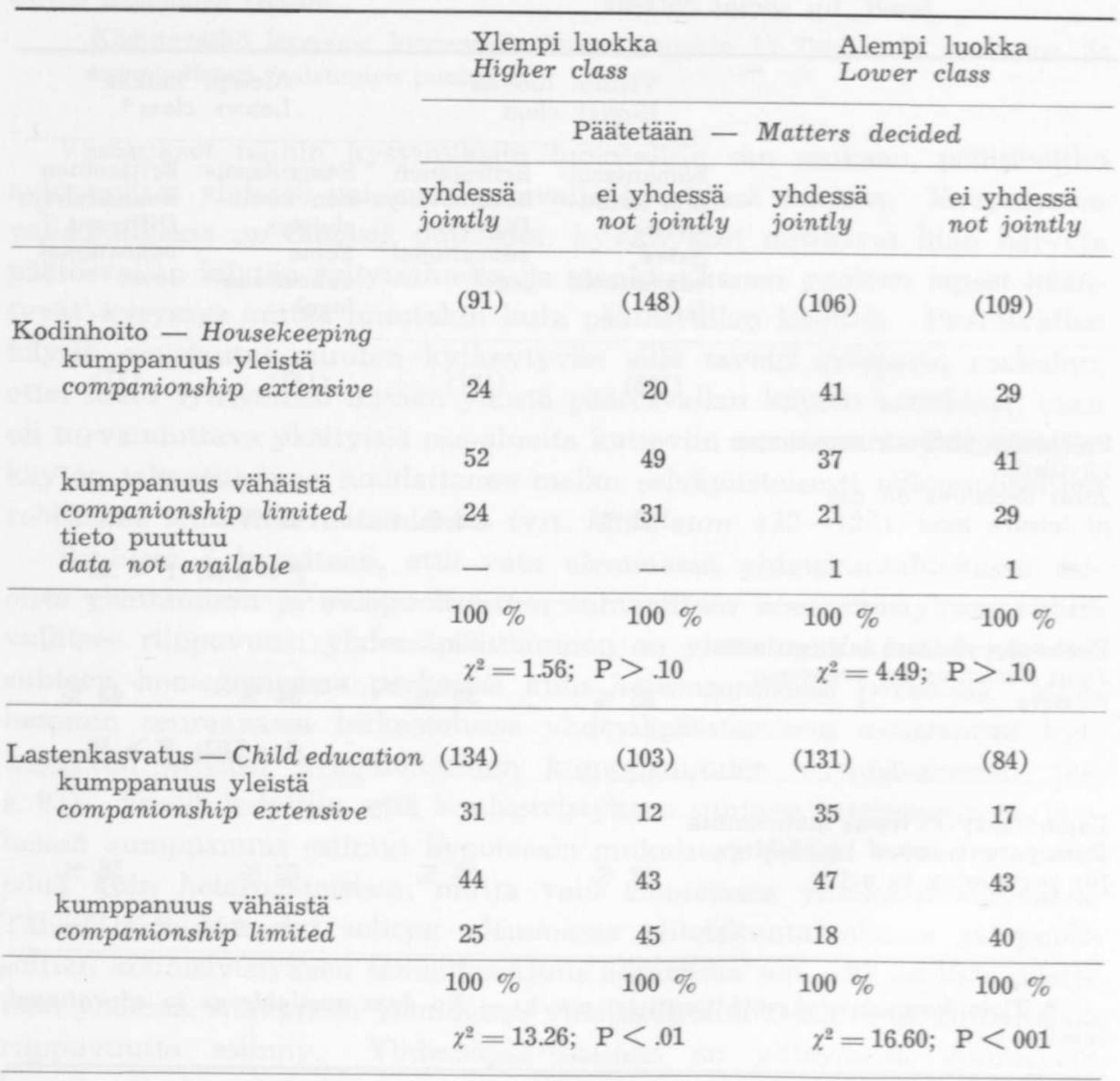

Vapaa-ajan käyttö - Use of

leisure time

kumppanuus yleistä

companionship extensive

kumppanuus vähäistä

companionship limited

tieto puuttuu

(93)

45

24

49

$55 \quad 75$

51

data not available

1

$100 \%$

$100 \%$

$-$

76

$\chi^{2}=9.14 ; \quad \mathrm{P}<.02$

$100 \%$

$100 \%$

$x^{2}-9.14 ; \mathrm{P}<.02$

$\chi^{2}=11.42 ; \quad \mathrm{P}<.01$

* Tieto puuttuu: päättäminen lastenkasvatuksessa $n=2$, päättäminen vapaa-ajan käytöstä $\mathrm{n}=27$. - No data available: decisions in child education $n=2$, decisions on use of leisure time $n=27$. 
mälle meneviä johtopäätöksiä ei aineistomme perusteella voida tehdä. Wolfe on kuitenkin todennut, että synkraattisuus on yhteydessä vaimojen tyytyväisyyteen, mitä tulee heidän pyrkimystensä toteutumiseen ja tarpeitten tyydyttämiseen (Wolfe, 115). Herbst päätyy väitteeseen: sosiaalisia jännityksiä voidaan vähentää vain siten, että vaivaudutaan pyrkimään yhteisiin päätöksiin ja osallistutaan yhdessä toimintoihin (Herbst, 169).

\subsection{Perheen kinteys ja kumppanuus}

Nykypäivien urbaaninen perhe on epävakaisempi kuin maaseutuperhe, jota vakauttavat toimintojen ja tehtävien kotikeskeisyys ja monet institutionaaliset siteet. Urbaanisen perheen koossapysyminen on suhteellisesti harvojen tehtäväsiteiden varassa. Perheen jäsenten monet pyrkimykset ja tehtävät ovat luonteeltaan yksilökeskeisiä ja kotipakoisia, kodin ulkopuolelle suuntautuvia (vrt. Goode, 204). Tällaista nykyajan perhettä on tästä syystä sattuvasti kutsuttu «hajaperheeksi (dispersed family). Viimeaikainen yhteiskuntaelämän kehitys viittaa siihen, että hajaperhe on yleistymässä, mutta merkitseekö tämä kehitys samalla koko perheinstituution asteettaista hajaantumista? Ainakin voidaan sanoa Karlssonin tapaan, että avioliitto on muuttumassa yksiavioisuudesta, monogamiasta, kohti peräkkäistä moniavioisuutta, polygamiaa: ollaan aviossa useiden kanssa - mutta ei samanaikaisesti (Karlsson, 1959, 76).

Hajaperheen hajaantumisalttius on kiinnittänyt tutkijoiden huomiota. Tutkimuksissa on pyritty paikallistamaan niitä häiriötekijöitä, jotka ovat yhteydessä avioliiton kiinteyden heikkenemiseen. Tässä tarkastelussa on huomio kiinnitetty lähinnä aviopuolisoitten yhteisosallistumiseen, kumppanuuteen. Kumppanuus on osoittautunut eräissä aikaisemmissa tutkimuksissa olevan yhteydessä perheen kiinteyteen. Pienryhmätutkimuksissa tukea saanut hypoteesi: vuorovaikutus synnyttää mieltymystä - ellei se herätä ärtymystä, pitänee myös perheen kohdalla paikkansa, ja kumppanuus edistänee näin ollen aviopuolisoitten tyytyväisyyttä, perheen koossapysymistä ja kiinteyttä. Blood ja Wolfe ovat todenneet, että vaimojen aviollisen tyytyväisyyden ja kumppanuuden välillä on selvä riippuvuus. Tutkijat ovatkin päätyneet seuraavaan toteamukseen:

-Ihmiset tarvitsevat toisiaan. Kontaktin puute toisiin ihmisiin on vakavan henkisen sairauden oire. Mutta kumppanuus on jotain muutakin kuin vain toisten lähellä olemista. Se merkitsee toisen läsnäolon arvostamista. Kokemusten jakaminen läheisen ystävän kanssa synnyttää mielihyvää ja antaa myös tyytyväisyyttä... Halu elää yhdessä on avioliiton oleellisin puoli» (Blood-Wolfe, 260).

Karlsson on väittänyt, että aviollinen tyytyväisyys perustuu suuresti siihen, mitä aviopuolisot odottavat toisiltaan ja miten nämä odotukset 
täyttyvät (Karlsson, 1951, 25). Edellisen perusteella näyttää siltä, että ainakin vaimot odottavat usein miehiltä kumppanuutta ja että kumppanuus aikaansaa osaltaan aviollista tyytyväisyyttä. Kumppanuus voi lujittaa ystävyyttä, ja sen säilyminen on Nelson N. Footen mielestä välttämätöntä, jos avioliitto nojautuu ensi sijassa juuri miehen ja vaimon keskinäisten suhteiden varaan (Foote, 26 ).

Aviopuolisoitten kumppanuus on yleensä kasautuvaa: jos kumppanuutta esiintyy jollakin alalla, niin sitä esiintyy todennäköisesti muillakin aloilla. Samoin kasautuu kumppanuuden puute. Tutkimuksen alemmassa yhteiskuntaluokassa, joka käsitti miehen ammatin perusteella työväestöön kuuluvat, kumppanuus kasautui selvemmin kuin ylemmässä luokassa. Tämä selittyy osittain sillä, että työväenluokan vaimoista suhteellisesti suurempi osa kuin ylemmän luokan vaimoista käy ansiotyössä perhekohtaisista syistä, ja näissä perheissä kumppanuus on yleisempää kuin muissa vaimo-ansiotyössä-perheissä. Vaimon ansiotyöllä saattaa kumppanuutta lisäävänä olla lasten sosialisaatioon vaikuttavien häiriöfunktioiden ohessa myös perheen kiinteyttä ja pysyvyyttä edistäviä funktionaalisia seuraamuksia. Yhteisosallistuminen perheen taloudellisen toimeentulon hankintaan on usein yhteydessä kumppanuuteen muillakin aloilla. Weil, jonka mukaan kumppanuus on päättämisen ja vastuun jakamista avioelämässä, on todennut yhtäpitävästi, että kumppanuusroolin omaksuneitten vaimojen osuus ansiotyöhön osallistumisessa on suurempi kuin traditionaalisen roolin omaksuneiden vaimojen (Weil, 91, 93-94).

Kumppanuuden ongelma ratkaistaan luultavasti eri yhteiskuntaluokissa toisistaan poikkeavalla tavalla. Kumppanuuden kasautuneisuus työväestön parissa on osoituksena siitä, että aviopuolisoitten roolit ovat jossakin määrin diffuusit. Kumppanuuden vähempiasteisen kasautuneisuuden ylemmässä luokassa ei suinkaan tarvitse merkitä sitä, että kumppanuus olisi tässä yhteiskuntaluokassa vähäisempää. Sitä esiintyy, mutta se on eriytyneempää, eikä siis niin laajaulotteista kuin työväestön keskuudessa. Tämä voi johtua esim. siitä, että ylemmässä luokassa on sosiaaliseen kohoamiseen pyrkiviä, menestystä ammattiuralleen tavoittavia suhteellisesti enemmän kuin työväestön parissa, ja näiden aviomiesten sidonnaisuus työhönsä saattaa estää ainakin laaja-alaista kumppanuutta. Blood ja Wolfe ovatkin todenneet, että ammattiuralla eteenpäin pyrkiminen tapahtuu usein perheosallistumisen kustannuksella, kun taas turvallinen, stabiili sosiaalinen asema edistää perhekumppanuutta (Blood-Wolfe, 61). Samat tutkijat ovat havainneet myös, että suurituloisilla aviomiehillä on kumppanuuteen nähden erityisen tyytymättömät aviovaimot. Vaimot odottavat enemmän kumppanuutta, ja miehet ovat liian sidottuja työhönsä pystyäkseen täyttämään sellaisia odotuksia (169-170). Goode tarjoaa tähän miesten kumppanuuden puutetta koskevaan vaimojen tyytymättömyyteen toisenkin huomionarvoisen selitysmahdollisuuden. Gooden mukaan aviomies on traditionaalisesti selvästi vähemmạn kiinnostunut per- 
heestä ja hänen viettymyksensä (attraktio) suuntautuu jo 'luonnostaan' perheen ulkopuolelle. Nykyaikana tästä on tullut kuitenkin vaimoille periaatteellinen tasa-arvoisuuskysymys, ja siksi vaimot valittavat aviomiestensä käyttäytymisen johdosta enemmän kuin aikaisemmin (Goode, 135).

Aviopuolisoitten sosiaalisen taustan ja persoonallisuuden piirteiden samankaltaisuuden on todettu aikaisemmissa tutkimuksissa olevan yhteydessä aviolliseen tyytyväisyyteen. Samankaltaisuus näissä suhteissa merkinnee samalla aviopuolisoitten pyrkimysten ja odotusten samansuuntaisuutta sekä elämäntapojen yhtäläisyyttä, mitkä vuorostaan voivat edistää myös kumppanuutta (vrt. Blood—Wolfe, 256). Tarkasteltavassa tutkimuksessa todettiin koulusivistyksen suhteen homogamisissa perheissä kumppanuuden olevan vähässä määrin yleisempää kuin heterogamisissa perheissä, mutta vain työväestön parissa. Tämä tulos selittyi sillä, että työväestön keskuudessa aviopuolisoitten koulusivistyksen samantasoisuus oli yhteydessä siihen, että perheen asioista päätetään enemmän yhdessä, ja yhdessäpäättäminen on vuorostaan yhteydessä kumppanuuden aktivoitumiseen. Tutkimuksen ylemmässä luokassa ei sitävastoin tällaista riippuvuusketjua ollut havaittavissa. Aviopuolisoitten sosiaalisen taustan samankaltaisuus on kuitenkin vain e räs sellainen tekijä, kuten Foote huomauttaa, joka saattaa edistää puolisoitten yhteensopivuutta (Foote, 27-28).

Nyt suoritetun tutkimuksen perusteella ei ole voitu selittää minkälainen yhteys vallitsee kumppanuuden ja aviollisen tyytyväisyyden tai perheen kiinteyden välillä. Amerikkalaiset tutkimustulokset viittaavat kuitenkin siihen, että aviopuolisoitten kumppanuus ja perheen kiinteys esiintyvät usein rinnan, samoin niiden puute. Toisaalta on ilmeistä, ettei ainakaan laaja-asteinen kumppanuus yhteisosallistumisen mukaan määriteltynä ole a in a aviollisen tyytyväisyyden ja perheen kiinteyden välttämätön edellytys. Tätä väitettä tukee havainto, että kumppanuus avioliiton alkuaikoina on yleisempää kuin myöhemmin. Aviollinen tyytyväisyys perustunee avioliiton varhaiskautena etupäässä juuri kumppanuuteen, yhdessä olemiseen ja yhteisosallistumiseen, mutta myöhemmin tyytyväisyys saavutetaan ehkä muulla tavalla, tai ehkä kumppanuus tarvitsee silloin, pysyäkseen elävänä ja perheen kannalta funktionaalisena, rinnalleen myös aviopuolisoitten erillään oloa ja itsenäistä ajankäyttöä (vrt. Foote, 29). Tietysti on sellaisiakin aviopareja, jotka eivät koskaan väsy toisiinsa, mutta nämä ovat poikkeuksia, kuten Nelson Foote huomauttaa (Foote, 27).

Kumppanuutta muodossa tai toisessa esiintyy kaikissa avioliitoissa, sillä on vaikea kuvitella perhe-elämää ilman sitä (vrt. Herbst, 146). Kumppanuuden optimiastetta on kuitenkin vaikea määrittää. P. G. Herbst väittää, että optimi on jossakin synkraattisen ja autonomisen perhejärjestelmän välillä, jossa sosiaaliset ja taloudelliset toimet ovat pääasiassa yhteisiä, mutta jossakin määrässä suovat aviopuolisoille tilaisuuden myös itsenäiseen toimintaan. Täten saavutettaisiin terve tasapaino yhteisosallistumiseen perustuvan ryhmätoiminnan ja henkilökohtaisen, itsenäisen yksilö- 
toiminnan välillä (Herbst, 172). Nykyperheessä yksilön ja ryhmän tarpeet joutuvat helposti ristiriitaan. Ralph Linton suosittelee tähän samantapaista ratkaisua kuin Herbst: "Aviopuolisoilla on oltava riittävästi yhteisiä harrasteita pitämässä heitä yhdessä ja riittävästi ulkopuolisia ja henkilökohtaisia harrasteita estämässä heitä kyllästymästä toisiinsa (Linton, 100-101).

\section{Kirjallisuus}

Allardt, Erik, Miljöbetingade differenser i skilsmässofrekvensen, Helsingfors, 1953.

Benson, Purnell, The Interests of Happily Married Couples; Sussman (ed.), Sourcebook in Marriage and the Family, Cambridge, Mass., 1955.

Blood, Robert O. (Jr.) - Wolfe, Donald M., Husbands and Wives, Glencoe, 1960.

Burgess, Ernest W. - Locke, Harvey J., The Family - from Institution to Companionship, New York, 1945.

Burgess, Ernest W. - Wallin, Paul, Engagement and Marriage, New York, 1953.

Eskola, Antti, Aviopuolisoiden roolijakoon vaikuttavat tekijät. Väestötutkimuksen vuosikirja VI - 1960, Vammala, 1960.

Foote, Nelson N., Matching of Husband and Wife in Phases of Development, Transactions of the Third World Congress of Sociology, Vol. IV, London, 1956.

Goode, William J., After Divorce, Glencoe, 1956.

Heider, Fritz, The Psychology of Interpersonal Relations, New York, 1958.

Heinilä, Kalevi, Vapaa-aika ja urheilu, Porvoo, 1959.

Herbst, P. G., Family Living - Regions and Pathways, Oeser - Hammond (ed.), Social Structure and Personality in a City, London, 1954.

Herbst, P. G., Family Living - Patterns of Interaction, Oeser - Hammond (ed.), Social Structure and Personality in a City, London, 1954.

Homans, George, The Human Group, London, 1951.

Hultgren, Sten - Stoltz, Ingmar, Aktenskapet och lyckan, Stockholm, 1956.

Karlsson, Georg, Adaptability and Communication in Marriage, Uppsala, 1951.

Karlsson, Georg, Barnfamiljernas ekonomi och äktenskapets stabilitet; Boalt m.fl., Vad händer med familjen, Stockholm, 1959.

Kohn, Melvin L. - Carrol, Eleanor E., Social Class and the Allocation of Parental Responsibilities, Sociometry no. 4, 1960.

Lewin, Kurt, Studies in Group Decision, Cartwright - Zander (ed.), Group Dynamics, New York, 1953.

Linton, Ralph, Women in the Family, Sussman (ed.), Sourcebook in Marriage and the Family, Cambridge, Mass., 1955.

Mead, Margaret, Mies ja nainen (suom. kirjasta Male and Female), Helsinki, 1957.

Middleton, Margaret R., Trends in Family Organization in Australia, Oeser Hammond (ed.), Social Structure and Personality in a City, London, 1954.

Thibaut, John W. - Kelley, Harold, H., The Social Psychology of Groups, New York, 1959.

Walker, Helen M. - Lev, Joseph, Statistical Inference, New York, 1953.

Weil, Mildred W., An Analysis of the Factors Influencing Married Women's Actual or Planned Work Participation, American Sociological Review no. 1, 1961.

Wolfe, Donald M., Power and Authority in the Family, Cartwright (ed.), Studies in Social Power, Ann Arbor, 1959. 


\title{
Summary:
}

\section{Family Companionship and Family Cohesion}

\author{
By KALEVI HEINILA \\ Institute of Sociology, Helsinki University
}

The study here under review deals with cohesion in the urban family of today. We know, that the tendency towards disintegration visible in this family type - also called sthe dispersed family - relates i.a. to the continual shrinkage of the family's sphere of duties and weakening of institutional bonds in general. Further, some investigators have discovered a connexion existing between family cohesion and the companionship of spouses. In the present analysis, whose material was collected in a series of interviews made with 454 married women in Helsinki, a view is taken of the companionship of spouses - defined as a joint participation - in housekeeping, in directing the socialization of their children, and in the use of leisure. The examination shows that companionship is cumulative in these fields: if it appears in one field, it will appear in others as well. Similarly cumulates lack of companionship. The most essential hypotheses of the present analysis are:

1. Where the interaction of several persons is increasing, the feeling of mutual affection that exists between them likewise gains in strength - and vice versa: companionship and marital satisfaction correlate positively.

2. Where the interaction of the members of a group belonging to an external system is a lively one, the members become attached to each other, and this again will lead to the continuance of the interaction beyond that demanded by the external system in point: if there appears companionship in the performance of a family's domestic duties, it will appear likewise outside the home, in the spouses' use of their leisure.

3. Such wage-earning activity of the wife's as she engages in for family considerations, as e.g., to provide her family with a living, stands in relation to companionship: in families with wives thus engaged, companionship is more extensive than in those families where the wives carry on some wage-earning activity rather for personal considerations.

4. During the initial period of a marriage the roles of the spouses are diffuse: in younger marriages companionship is more extensive than in older.

5. Similarity of background will create attachment; attachment, on the other hand, interaction: in homogamous families companionship is more extensive than in heterogamous.

6. In syncratic families, where the spouses decide jointly on different matters, companionship is more extensive than in non-syncratic families.

On the whole, these hypotheses were supported by facts. As in certain earlier investigations, it came out in this one too, that in families with a wife being engaged in wage-earning work, companionship was altogether more extensive than in families where the wife stayed at home. Joint participation in activities for safeguarding the family's financial condition proves to be functional, as regards its consequences to 
the family, at least in so far, that the companionship obtaining between spouses who behave thus will grow stronger likewise in their other fields of activity.

While it is apparent that the companionship of spouses relates to family cohesion, it does not follow, that companionship - still taken by the definition as sjoint participation» - however wide in range, were in itself an indispensable prerequisite of family cohesion. This proposition is borne out by the observed fact that at an early stage of marriage, companionship is more extensive than subsequently. During this initial period, marital satisfaction seems to rest, primarily, just on companionship, on being together in general, and on joint participation in different activities. Later, satisfaction is perhaps reached by other means, or it is possible, that companionship, for being able to preserve its vitality, and to remain functional from the standpoint of the family, then requires side by side with itself, at least to some extent, mutual isolation and independent use of time on the part of the spouses. 